\title{
PRACTICAL ASPECTS OF IMPLEMENTATION OF QUALITY MANAGEMENT SYSTEM REQUIREMENTS FOR THE MEDICAL FOOTWEAR DESIGN
}

\author{
Daniel PETCU*, Viorica ROȘCULET \\ INCDTP - Division: Leather and Footwear Research Institute, 93 Ion Minulescu St., Bucharest, Romania, \\ email: crispinian.ro@gmail.com
}

Received: 06.12.2017

Accepted: 05.03.2018

https://doi.org/10.24264/Ifj.18.1.5

PRACTICAL ASPECTS OF IMPLEMENTATION OF QUALITY MANAGEMENT SYSTEM REQUIREMENTS FOR THE MEDICAL FOOTWEAR DESIGN ABSTRACT. A quality management system in place and functioning can be certified by a neutral body, third party, that certifies compliance of the design process of the medical footwear to the reference specifications in this field. In states where pedorthics is developed, professional associations provide an accreditation of facilities that are operating in the design and production of pedorthic devices. Another option for conformity certification in the field of medical devices consists in demonstrating that quality management system (QMS) of the organization complies with the requirements of the standard reference in the field, respectively SR EN ISO 13485: 2016 "Medical devices. Quality management systems. Requirements for regulatory purposes". Design work carried out according to the requirements of this standard contributes to the development of medical devices complying with the regulations in this field for the benefit of the patient. This paper aims to present practical aspects of implementing the quality management system requirements for the design of medical footwear, applicable to small and medium companies.

KEY WORDS: medical footwear design, conformity assessment, certification, quality management system

\section{ASPECTE PRACTICE PRIVIND IMPLEMENTAREA CERINTELOR SISTEMULUI DE MANAGEMENT AL CALITĂTII ÎN PROIECTAREA ÎNCĂLTĂMINTEI MEDICALE}

REZUMAT. Un sistem de management al calităţii implementat şi funcțional poate fi certificat de către un organism neutru, de terță parte, care atestă conformitatea procesului de proiectare a încălțămintei medicale în raport cu specificațiile de referinţă din acest domeniu. În statele în care pedorthica este dezvoltată, asociaţiile profesionale oferă un sistem de acreditare al facilităţilor în care se desfăşoară activitatea de proiectare şi producție a dispozitivelor medicale specifice. $\mathrm{O}$ altă opţiune pentru certificarea conformităţii în domeniul dispozitivelor medicale constă în demonstrarea faptului că Sistemul de Management al Calității (SMC) al organizației este conform cu cerințele standardului de referință din domeniu, respectiv SR EN ISO 13485:2016 „Dispozitive medicale. Sisteme de management al calității. Cerințe în scopuri de reglementare”. Desfăşurarea activității de proiectare în raport cu cerințele acestui standard contribuie la dezvoltarea unor dispozitive medicale conforme cu reglementările din acest domeniu, în beneficiul pacientului. Lucrarea de față îşi propune să prezinte aspecte practice privind implementarea cerinţelor sistemului de management al calităţii în proiectarea încălţămintei medicale, aplicabile în cazul firmelor mici şi mijlocii.

CUVINTE CHEIE: proiectarea încălţămintei medicale, evaluarea conformității, certificare, managementul calității

\section{ASPECTS PRATIQUES DE LA MISE EN đUUVRE DES EXIGENCES DU SYSTÈME DE GESTION DE LA QUALITÉ DANS LA CONCEPTION DE} CHAUSSURES MÉDICALES

RÉSUMÉ. Un système de gestion de la qualité mis en œuvre et fonctionnel peut être certifié par un organisme tiers neutre qui certifie la conformité du processus de conception de chaussures médicales avec les spécifications de référence dans ce domaine. Dans les pays où le domaine de la pedorthics est développé, les associations professionnelles offrent un système d'accréditation des installations dans lesquelles la conception et la production de dispositifs médicaux spécifiques sont effectuées. Une autre option pour la certification de conformité dans le domaine des dispositifs médicaux est de démontrer que le système de gestion de la qualité (SMC) de l'organisation est conforme aux exigences de la norme de l'industrie, SR EN ISO 13485: 2016 “Dispositifs médicaux. Systèmes de gestion de la qualité. Exigences réglementaires". Le développement de l'activité de conception en relation avec les exigences de cette norme contribue au développement de dispositifs médicaux conformes à la réglementation dans ce domaine, au bénéfice du patient. Cet article vise à présenter des aspects pratiques concernant la mise en œuvre des exigences du système de gestion de la qualité dans la conception de chaussures médicales, applicables aux petites et moyennes entreprises.

MOTS-CLÉS: conception de chaussures médicales, évaluation de la conformité, certification, gestion de la qualité

\footnotetext{
* Correspondence to: Daniel PETCU, INCDTP - Division: Leather and Footwear Research Institute, 93 lon Minulescu St., Bucharest, Romania, email: crispinian.ro@gmail.com
} 


\section{INTRODUCTION}

\section{Aspects of Conformity Assessment through Certification Practice}

Certification is defined as third-party attestation, by an accredited neutral body, that a product, process or person conforms to the reference specifications, which can be a standard, a rule or a technical document, and so on [1]. Design work involves preparing a "technical project on a given topic, comprising technical and economic calculations, drawings, instructions, and so on, necessary for the execution of a building, a car, and so on" [2]. Thus, one of the activities of the design process is the "development of specifications" included in SR EN ISO 13485: 2016 "Medical devices. Quality management systems. Requirements for regulatory purposes" [3]. In conformity with SR EN ISO 9000:2015 "Quality management systems - Fundamentals and vocabulary", "design and development" is defined as "a set of processes that transform the requirements for an object into more detailed requirements for attaining that object" [4]. The requirements that form inputs can be expressed in a more general sense than requirements forming the output of the design and development process. Thus, for the process of designing medical footwear, prescription is constituted as an input. The prescription concept implies that the prescription form includes specific design features in accordance with the definition of medical custom-made devices but in reality this does not happen in current practice [5-7].

The solution proposed according to the medical literature was to develop prescription items in the following components:

- medical prescription containing medical objective and functional description,

- technical prescription containing specific design features of the medical device. These characteristics should allow the practical realization (manufacturing) of the medical device.

In this way, the responsibilities and competencies of the interdisciplinary team which should develop the conservative treatment of the foot mechanical pathologies with medical footwear can be defined more clearly.

In Romania the most common certification activity in the field of medical devices is the certification of the organization's quality management system (QMS) in accordance with the requirements of reference in the field, respectively SR EN ISO 13485: 2016 "Medical devices. Quality management systems. Requirements for regulatory purposes".

In states with tradition in designing medical footwear such as USA, the certification is done:

- both at individual level, the specialist being "Certified Pedorthist", who is working in health profession as a paramedical profession, being trained to apply a conservative treatment with medical footwear for a given patient,

- and at the company level, this being applied separately for companies that offer medical services to patients ("Patient Care"), or companies that offer medical devices design/ manufacturing services, or those providing clinical care services.

In these countries professional organizations play a key role in providing certification services. In this respect, the American Board for Certification in Orthotics, Prosthetics \& Pedorthics (ABC) can be given as an example of the professional association that provides certification services [8, 9]. According to data published on the website of $A B C$ Association, which is the national accreditation and certification centre in the orthotics, prosthetics and pedorthics field, it has conducted over 13,000 certifications of specialists and over 7,000 accreditations of companies in these sectors since 1948 [8].

A program dedicated to certification of the companies in the pedorthics field is developed by The College of Pedorthics of Canada $[9,10]$. Belgium has developed a model of accreditation of care clinics dedicated to foot in which one of the criteria for recognition involves including a footwear technician in the treatment's multidisciplinary team [11]. Data collection and analysis and audits are conducted by an independent organization, Scientific Institute of Public Health (WIV-ISP) [11].

In the absence of specific medical footwear professional organizations, the base reference for certification of the design activities is the standard SR EN ISO 13485: 2016“"Medical devices. Quality management systems. Requirements for regulatory purposes". According to this standard the organization is expected:

- to identify its role in accordance with applicable regulatory requirements; 
- to identify the regulatory requirements that apply to its activities in these roles;

- to implement these applicable regulatory requirements to its quality management system.

Defining the role of the organization has an essential importance because its area of expertise is defined depending on the assumed role.

According to a study based on a "Questionnaire on activities related to prescribing, design and production of therapeutic and orthopedic footwear, and medical devices placed in shoes" [13], in Romania, companies operating in this market since 2001 have an average of 7 employees (a minimum of 2 , maximum 17) involved in the design and execution activities of these types of medical devices. Share activities of these companies were as follows: $41.7 \%$ - footwear production; $48.8 \%$ - orthotic / prosthetic, $0 \%$ - recovery of health; 9.5\% - other activities (e.g. commercial activities). All companies surveyed said they produce footwear, while $66.7 \%$ also conduct orthotic-prosthetic activities. It is noteworthy that in 2017 by accessing the websites of 15 companies producing orthopedic footwear in Romania which are in contractual relations with national insurance agency only two companies were identified that have posted on the website information on the implementation of QMS, one of which has posted online certificates for manufacture and service of custom-made medical devices (SR EN ISO 9001:2008 and SR EN ISO 13485:2012), while the other mentions only "ISO certification" without specifying the standard by which they achieved certification.
FOR THE MEDICAL FOOTWEAR DESIGN

Viewed from the perspective of company size and qualification of specialized personnel, implementation of a quality management system can be seen as a time and resource consuming process. This paper presents a way to implement the requirements regarding the medical footwear design activities that can be useful in the management of small companies.

\section{QMS REQUIREMENTS IMPLEMENTATION}

The implementation of the quality management system procedures and forms can be made practical through a database that can be obtained in a simplified manner by using an accessible software solution such as Microsoft Excel. The database structure must meet all the requirements of SR EN ISO 13485. These requirements can be grouped into two categories depending on the connection they have with the central activity of custom-made medical devices design, namely:

- "general" requirements regarding the context of the organization, leadership, support, planning, and so on,

- "specialized" requirements that are crucial to the design process such as: operating, performance evaluation, improvement.

To do this, first the initial settings of the system and their way of relating have to be established. Figure 1 presents quality management system processes regarding the design process. This paper focuses on processes with an immediate key role to design processes, namely: the operation, performance assessment and activities improvement.

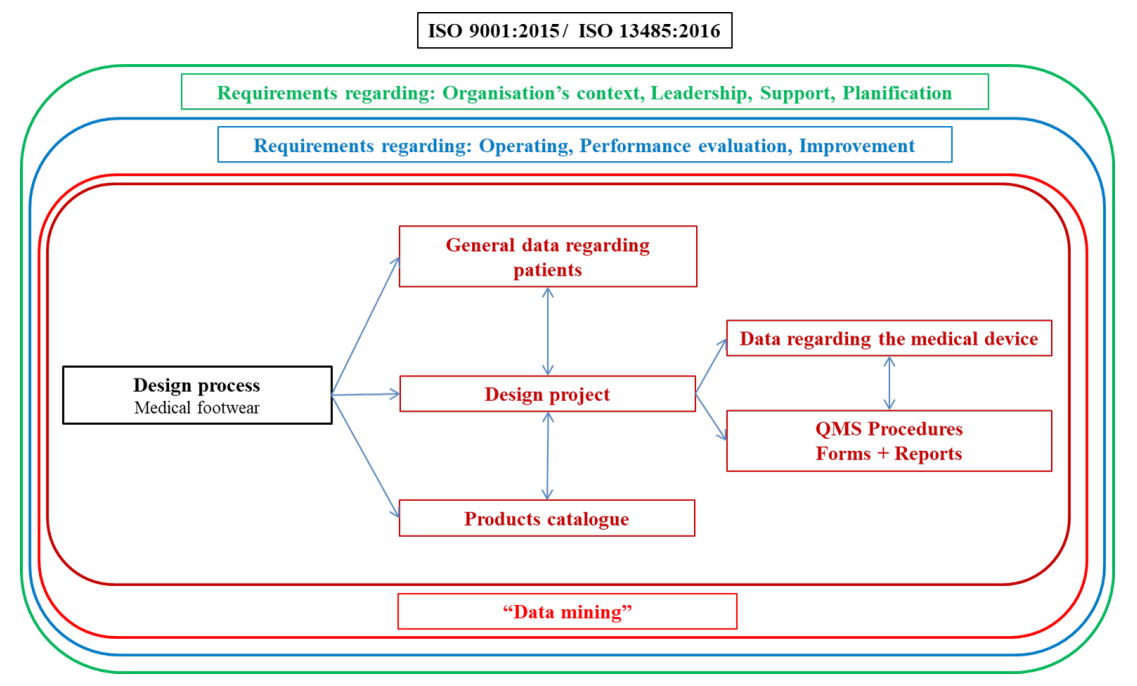

Figure 1. Processes of quality management system 
Given the nature and scale of the medical footwear design activities, based on the requirements of ISO 13485: 2016 the following procedures and forms have been documented:

\section{Procedures}

1. "Design - development and risk management" procedure, code P-73, establishes the methods used by the function of design and development to ensure compliance to specific design characteristics contained in the medical prescription with the technical specifications of medical device design and risk management related to design.

2. "Storage and control of conformity design" procedure, code P-7511, describes the measures taken on how the design is carried out keeping compliance during internal processing and delivery to the recipient.

3. "Feedback and relationship with the customer" procedure, code P-72, describes the measures taken on how to carry out:

- identification and analysis of design requirements;

- effective communication with customers on information about the design, about the experience of post stage design, supply and demand, contracts and orders, complaints and reminders;

- QMS performance measurement on the customer's perception of the degree to which their requirements were satisfied and analysis of the experience in post design phase.

4. "Identification and traceability" procedure, code $P$ 758-9. The purpose of this procedure is to describe methods and responsibilities that have been taken to identify the design throughout its manufacturing to ensure that the design project returned to the organization is identified and distinguishes from conforming design as well as to identify design progress in relation with requirements for measuring and monitoring. The procedure also describes how extensive traceability and design unique identification are ensured.

5. "Control of nonconforming design" procedure, code P-83, defines operational means and responsibilities provided for control of the design project that did not pass inspections and checks in accordance with the acceptance criteria set out or in case of complaint or requiring notification to third parties, the withdrawal of nonconforming designs. The designs are stored under control to avoid use and/or unintentional delivery.

6. "Corrective and preventive actions / learning from post-design experience" procedure, code $\mathrm{P}-85$, describes the method of determining the real and potential causes of nonconformities, implementing corrective and preventive actions and learning from postdesign experience. The procedure also describes the methods and responsibilities taken to determine and treat nonconformities of designs projects, services and to improve the system. The database also meets "Identification and traceability" procedural requirements.

\section{Forms}

- "Custom-made medical device design order form", code F1-F2, contains data on the beneficiary of design, the subject of the order and other terms such as design delivery together with the declaration of conformity,

- "Customer requirements data analysis form", code F2-72, determines whether an order is accepted or not based on analysis of requirements including standards and/or methods imposed by client, the existence of the necessary capability and financial conditions or delivery dates required to meet customer requirements,

- "Prescription", code PR. Prescription items were detailed in medical prescription and technical prescription,

- "Analysis and design validation", code F2-73, refers to the evaluation of the analysis, verification and validation processes of the design, specifying references, observations or changes where necessary,

- "Customer Satisfaction Questionnaire", code F3-72, for establishing a customer given rating based on various criteria such as design quality, quality-price ratio, relationship with organization employees, complaint resolution, organization flexibility regarding special customer requirements. Also through this questionnaire the customer is asked to indicate whether he will recommend services to other potential customers,

- "Nonconformity report and corrective/ preventive actions for the design", code F1- 
85, contains data about designs relating to internal complaint or learning from post-design experience, the causes for the occurrence of nonconformities, directives issued to remedy the situation and reporting corrections or preventive actions. It determines both whether the design will be reviewed and the effectiveness of corrective and preventive action,

- "Nonconformity report and corrective/ preventive actions for the process", code F2-85, is similar with F1-85 form but refers to the QMS nonconformities.

The forms are annexes of the procedures, used for data collection and are listed in Table 1. All forms are constructed as Excel files so as to allow data analysis at any time. Database construction was based on an Excel file that contains three sheets named "Main", "Data Analysis" and "Menu". Database fields organised according to the procedures described above are:

- "Order" - according to form F1-72,

- "Prescription" - according to form P,

- "Design" - refers to medical device documents and virtual files,

- "Execution stage of design" - describes the execution stage of design,

- "Analysis, verification and validation of design" - according to form F2-73,

- "Customer satisfaction" - displays the rating given on the evaluation questionnaires according to form F3-72,

- "Control of nonconforming design" according to form F1-85,

- "Nonconformity, corrective action, postdesign experience", - according to form F2-85,

- "Virtual catalogue" - contains media of manufactured medical devices.

Table 1: Correspondence between database fields and QMS procedures and forms

\begin{tabular}{|c|c|c|c|}
\hline No. & Field/ Form & Procedure & Form Code \\
\hline 1 & Order & Feedback and customer relationship & $\begin{array}{l}\text { F1-72 } \\
\text { F2-72 }\end{array}$ \\
\hline 2 & General information on patients & Design and development and risk management & PR \\
\hline 3 & Data on medical devices & Design and development and risk management & PR \\
\hline 4 & Analysis, verification and validation of design & Design and development and risk management & F2-73 \\
\hline 5 & Customer satisfaction / Qualification & Feedback and customer relationship & F3-72 \\
\hline 6 & Control of nonconforming design & Control of nonconforming design & F1-85 \\
\hline 7 & $\begin{array}{l}\text { Nonconformity, corrective action, post-design } \\
\text { experience }\end{array}$ & $\begin{array}{l}\text { Corrective and preventive actions / learning from } \\
\text { post-design experience }\end{array}$ & $\mathrm{F} 2-85$ \\
\hline
\end{tabular}

A record in the database corresponds to an order. Data entry was facilitated by using the so-called "drop-down list" which the operator uses to choose an option for a given cell from a list containing all the options defined for the field at a certain time. Thus, by selecting a cell in fields that have such a menu implemented, a specific message is displayed which indicates the action to be taken. For example, by selecting a cell in the "Execution stage of design", the "Choose the design stage" message will be displayed while by selecting the button opening the options list, the selection of design stage is achieved. All the positions corresponding to the abovementioned fields are defined for a total of 25 records in the "Menu" sheet. Thus, for example, the list of diagnoses contained in the medical prescription can be updated at any time without requiring any changes except for updating the corresponding lists from "Menu" sheet. The "Data analysis" sheet shows the results of database queries made directly using the standard options of the application or by creating subroutines according to analyses that need to be made. This section provides data conforming on other QMS procedures specifications such as "Data Analysis" and "Management analysis" and "Storage and control of conformity design".

Benefits obtained from implementing such a quality management system for the design process through a database are numerous:

- database provides an overview of the inputs, processes and outputs that govern the design,

- allows maintaining system operation through warnings that occur when there is a 
nonconformity, such as au unsatisfactory rating given by a patient,

- allows real-time analysis and correlations between the factors involved in the design: medical prescription, technical prescription, patient data, patient feedback, and so on,

- allows data mining and enhancing expertise by learning from post-design experience.

\section{CONCLUSIONS}

Implementation and certification of a quality management system in the design activity of custom-made medical devices is a voluntary choice that ensures and enhances the efficiency of the compliance activity of the medical footwear design. Application of standard SR EN ISO 13485: 2016 "Medical devices. Quality management systems. Requirements for regulatory purposes" in companies or departments of companies with a small staff number needs an adaptation of necessary procedures and forms so as to enable implementation of QMS not seen as time and resource consuming. The advantages of implementing such a quality management system justify the effort. Since the implementation of this system is voluntary, the decision on its implementation is essential and it is the responsibility of decision makers.

\section{REFERENCES}

1. ISO/IEC 17000:2004 Preview Conformity assessment - Vocabulary and general principles, https://www.iso.org/ standard/29316.html.

2. "Proiectare" definition, DEX Online, Copyright (C) 2004-2018, https://dexonline.ro/ definitie/proiectare.

3. Medical devices - Quality management systems - Requirements for regulatory purposes, Chapter 3, Terms and definitions, EN ISO 13485:2016, https://www.iso.org.

4. SR EN ISO 9000:2015 "Quality management systems - Fundamentals and vocabulary" https://www.iso.org/obp/ i/\#iso:std:iso:9000:ed-4:v1:en.

5. Directive 2007/47/EC of the European Parliament and of the Council of 5 September
2007 amending Council Directive 90/385/ EEC on the approximation of the laws of the Member States relating to active implantable medical devices, Council Directive 93/42/EEC concerning medical devices and Directive 98/8/ EC concerning the placing of biocidal products on the market, Official Journal of the European Union, 21.9.2007, http://eurlex.europa.eu.

6. Petcu, D., Rosculet, V., Regulations for the prescription of footwear al medical device, Leather and Footwear Journal, 2017, 17, 1, https://doi.org/10.24264/Ifj.17.1.8.

7. Petcu, D., Prescription variables for the medical footwear, Leather and Footwear Journal, 2017, 17 4, https://doi.org/10.24264/ Ifj.17.4.5.

8. American Board for Certification in Orthotics, Prosthetics \& Pedorthics, https://www.abcop. org/facility-accreditation/Pages/default.aspx

9. Accreditation, https://opedge.com/ ProductDirectory/Accreditation

10. Facility Accreditation Program, http:// www.cpedcs.ca/certification-exams/facilityaccreditation/

11. Facility Accreditation for Canadian Certified Pedorthists, http:// www.cpedcs.ca/documents/ FacilityAccreditationapplication_000.pdf

12. Morbach, S., Kersken, J., Lobmann, R., Nobels, F., Doggen, K., Van Acker, K., The German and Belgian accreditation models for diabetic foot services, Diabetes Metab Res Rev, 2016, Jan, 32 Suppl 1, 318-25, https://doi.org/10.1002/ dmrr.2752.

13. Petcu, D., Deselnicu, D., Guta, S.A., Berijan, G., Aspects regarding the development of the medical footwear industry in Romania, Proceedings of the 4th International Conference on Advanced Materials and Systems, ICAMS, 2012.

(C) 2018 by the author(s). Published by INCDTPICPI, Bucharest, RO. This is an open access article distributed under the terms and conditions of the Creative Commons Attribution license (http:// creativecommons.org/licenses/by/4.0/). 